\title{
Bacterial Vaginosis Screening
}

National Cancer Institute

\section{Source}

National Cancer Institute. Bacterial Vaginosis Screening. NCI Thesaurus. Code C92740.

A test done during pregnancy for the presence of Gardnerella vaginalis, Ureaplasma

urealyticum, Mycoplasma hominis, Mobiluncus, Prevotella and anaerobic bacteria. 